\title{
MOGYORÓDI GERGELY
}

\section{A rendőrök felvételi eljárása \\ a modern rendőrség jellemzői tükrében}

A modern rendőrségről, a modernizálás szükségességéről és lehetőségeiről jelentős mennyiségben születtek mủvek. Jóval kevesebb publikáció áll rendelkezésre a rendőrök kiválasztásáról vagy az alkalmassági kritériumokról. Ennek lehetséges okai közé a szolgálat viszonylagos rövid múltját (erről részletesen később lesz szó), valamint azt sorolom, hogy az újítások elsősorban belső szakanyagokban láttak napvilágot, nem pedig tudományos müvekben.

Úgyszintén kevés az olyan (naprakész) hazai szakirodalom, amely a kettő összefüggésének vizsgálatával foglalkozik.

A dolgozatban arra keresek választ, hogy a magyar rendörök jelenlegi felvételi eljárásában, követelményeiben megtalálhatók-e a modern rendőrség jellemzői.

A vizsgálatot a témához kapcsolódó fogalmak tisztázásával kezdem, majd a kiválasztás történetét mutatom be, végül pedig a szakirodalom feldolgozásával (ideértve a Nemzeti Közszolgálati Egyetem Rendészettudományi Karának felvételi statisztikáit és a külföldi rendőrségek bemeneti követelményeinek példáit is) elemzem a kérdéskört.

A magyar nyelv értelmezö szótára szerint a modern szó mint melléknév a következő jelentésekkel bír. Egyfelöl „a korral haladó, a maga müködési területén a legújabb szellemi és technikai vivmányokat ismerö, elfogadó és velük élö »személy «" ", másfelöl pedig ,, a legújabb kor igényeinek, felfogásának, szokásainak, divatjának, szellemi, tudományos és technikai fejlettségének megfelelö »dolog «"2.

Ugyanitt a kiválasztás fogalmáról ez olvasható: „, több (hasonló) dolog, személy közül való választás, kijelölés (vmely célra) "’.

A rendörség vonatkozásában, ha a rendészeti szakgimnáziumokba vagy a Nemzeti Közszolgálati Egyetem Rendészettudományi Karára való bekerülést vesszük alapul (mivel ezek a rendőrré válás elsődleges, de nem kizárólagos

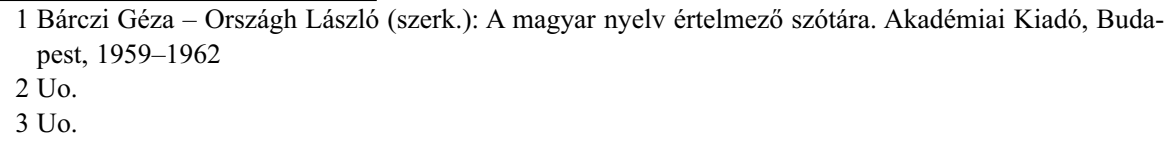


és megkerülhetetlen módjai), akkor a kiválasztás tulajdonképpen egy jogszabályok által meghatározott olyan folyamat, amely az adott tanintézmény követelményeinek, a szolgálati viszony létesítésének, valamint az alkalmasság kritériumainak való megfelelést jelenti. Másként megfogalmazva, a ,, személyi, képesitési, fizikai, pszichikai és egészségügyi alkalmassági követelményeknek" a teljesülése. ${ }^{4}$

Induljunk ki abból, hogy a korszerü rendészetre, ebből következően egy modern rendőrre jellemző a szakmai felkészültség és a megújulási készség. ${ }^{5}$

Az első kritérium teljesülélésében jelentős szerepe van a rendőrképzésnek. Köztudott, hogy egy jó termék előállításához rendszerint jó alapanyagok szükségesek. Nincs ez másként a rendőrök felkészítésével sem. A rosszul kiválasztott hallgatókkal nehéz a felkészítés és a fejlesztés, sok esetben pedig már az alapkiképzés ideje alatt bekövetkezik a pályaelhagyás, ezért fontosak a jól meghatározott bemeneti követelmények.

E gondolatmenet alapján, meglátásom szerint a következő kérdésekre kell és érdemes választ keresni:

- Ki tekinthető alkalmasnak (mitöl jó egy rendőrjelölt)?

- Mit jelent a rendőrhallgatók kiválasztásának professzionalizmusa?

- Lehet-e összefüggést találni egy hallgató hatékonysága (teljesítőképessége) és a jelenlegi bemeneti követelmények között?

A következőkben áttekintő jelleggel és a teljesség igénye nélkül, a kiválasztás történeti hátterén keresztül próbálok választ adni e kérdésekre. ${ }^{6}$

A mezei rendőrségről szóló 1840. évi IX. törvénycikk 21. szakasza már meghatározta, hogy „,csak hiteles, jó erkölcsü és még büntetéssel meg nem rovott emberek, és mindenkor csak az illetö szolgabíró vagy kapitány jóváhagyása mellett" lehetett szolgálati viszonyt létesíteni. Ekkor még csak személyi feltételekről beszélhettünk, alkalmassági kritériumok nem léteztek.

Az alkalmasságra vonatkozó első írott anyag a Budapest Székesfővárosi Magyar Királyi Államrendőrség 1894. évi müködési jelentése volt, amely felismerte, hogy a rendőri szolgálatellátáshoz magasabb követelményeknek

4 Csatai Tamás: A rendőrré válás és szolgálatellátás alatti pályaalkalmassági követelmények alakulása az 1800-as évek végétől napjainkig. Belügyi Szemle, 2010/7-8., 84. o.

5 Finszter Géza: A rendészet elmélete és a rendészeti eszközrendszer. Nemzeti Közszolgálati és Tankönyvkiadó Zrt., Budapest, 2013, 123. o.

6 A történeti rész feldolgozásához a következő tanulmányokat használtam fel: Krajcsovics Pál Félegyházi Csaba: Az egészségi alkalmassági vizsgálat társadalomorvostani és gazdasági vonatkozásai. Belügyi Szemle, 1997/12., 32-36. o.; Csatai Tamás: i. m. 
kell megfelelni. Innen datálható a központosított egészségügyi alkalmasság kialakulása ${ }^{8}$, amely a kritériumok területén sokáig egyeduralkodó volt. Az idő folyamán természetesen változtak a feltételek, így elősegítették az alkalmatlanság megállapítását. ${ }^{9}$

A korábbi rendszerekhez képest jelentős szemléletváltozást mutatott az 1981-ben kiadott egészségi alkalmassági táblázat.

Ez egyfelől rendelkezett a nem kielégítő fizikai teljesítőképességröl, azonban erőnléti alkalmassági vizsgálatokat még nem végeztek. Mivel az orvosok nem kizárólag egészségi kérdésekben döntöttek, ezért sporttiszteket is bevontak, kialakítva ezzel a kényszerítő teljesítmény értékelését (például szorító, csavaró, karoló stb.).

Másfelől a szolgálattal össze nem egyeztethető magatartási zavarok kiszürésére az orvosok pszichológusokat alkalmaztak, de a lélektani vizsgálatok továbbra sem különültek el.

Az előbbiek mellett újdonságnak számított az állománykategóriák (az A jelzésbe tartoztak a tanintézményekbe beiskolázottak) és a minősítési rendszer bevezetése is.

Az egységes, országos szintü vizsgálatokat 1985 -tő $1^{10}$ az Egészségügyi Alkalmasságot Vizsgáló Osztály (BM Korvin Ottó Kórház és Intézményei) látta el.

A 33/1997. (V. 13.) BM-IM-TNM együttes rendelet hatálybalépéséig az orvos kompetenciájába tartozott az alkalmasság kérdésének elbírálása. Ettől kezdve elkülönültek a pszichológiai és fizikai alkalmassági vizsgálatok, és megváltozott a minősítési rendszer is.

A fizikaiállapot-felméréseknél különbséget tettek a nemek és korcsoportok között, míg a pszichológiai vizsgálatok a személyiséget, a képességeket, és a rendőri pályára alkalmatlanná tevő betegségeket analizálták.

\footnotetext{
7 Krajcsovics Pál - Félegyházi Csaba: i. m. 32. o.

8 Krajcsovics Pál - Félegyházi Csaba - Körmendiné Szabó Beatrix: Az alkalmassági vizsgálat helye a Belügyminisztérium egészségügyi szolgálatában. Rendészeti Szemle, 1994/1., 67. o.

9 Fontos változás volt az egészségügyi alkalmassági táblázat kiadása 1961-ben, de a pszichológiai jellegü vizsgálatok továbbra sem különültek el. 1965-től a fővárosi rendőrség vonatkozásában a Belügyminisztérium Szakorvosi Rendelőintézet belgyógyásza, a vidéki rendőrségeken a rendőrorvos határozott az alkalmasság kérdésében. Mérföldkőnek számított a fegyveres erők és a fegyveres testületek hivatásos állományának szolgálati viszonyáról szóló az 1971. évi 10. számú törvényerejű rendelet, valamint a belügyminiszter végrehajtási utasítása, továbbá az alkalmassági vizsgálatok követelményrendszerét meghatározó 17/1973. BM parancs (Belügyminisztérium Egészségügyi Szabályzata). Lásd Csatai Tamás: i. m. 86. o.

10 A központosításról szóló döntés már 1980-ban megszületett.
} 
A korábbi szabályozást a 21/2000. (VIII. 23.) BM-IM-TNM együttes rendelet helyezte hatályon kívül. Bővült az orvosi, a fizikai és a pszichológiai vizsgálatok rendszere. Megváltoztak az alkalmassági kategóriák és a minősítések, de a folyamatok továbbra is az alkalmatlanság kiszürésére irányultak.

A szakterületek képviselői továbbra is különállóan döntöttek az alkalmasság kérdésében, emellett ebben az időben alakították ki a fizikai-pszichológiai-egészségi vizsgálati sorrendet is.

Ha az eddigi fejlődési irányt összességében figyeljük, egyértelmüen látható, hogy a rendőrök kiválasztása a klinikai alapú vizsgálatok irányába haladt. A hangsúly a megelőzésre, a kizáró és a szolgálatot veszélyeztető okokra helyeződött, míg az egyén alkalmazhatóságának kérdése háttérbe szorult.

Az előbbiekből következően jó rendőrjelöltnek az tekinthető, akinek megfelelő a végzettsége, megfelel a szolgálati viszony létesítésének, az orvostudomány, a lélektan és a testnevelés-tudományi szakmai kívánalmainak (röviden a társadalmi normákhoz alkalmazkodni tudó, kellően értelmes, testileg és lelkileg egészséges, jó erőben lévő személyek). Ebben érhető tetten a (kiválasztási) eljárás professzionalizmusa, valamint a hatékonyságra törekvés is (a kritériumok teljesülése esetén elvárható, hogy a hallgató jól teljesítsen).

A korábbiakban feltett kérdésekre nemcsak a történeti fejlödés áttekintéséböl, hanem az alkalmassági vizsgálatokat jelenleg szabályozó 57/2009. (X. 30.) IRM-ÖM-PTNM együttes rendeletben foglaltakban is találhatunk választ. Utóbbi 3. § (2) bekezdése ekként rendelkezik a professzionalizmusról: „Az egészségi és pszichikai alkalmassági vizsgálatokat a rendvédelmi szerv egészségügyi és pszichológiai szolgálata, az országos parancsnoksággal rendelkezö rendvédelmi szervek vonatkozásában az országos parancsnokság egészségügyi és pszichológiai szakirányitó szerve által kidolgozott, és a Belügyminisztérium Személyügyi Főosztály Egészségügyi Koordinációs Osztály (a továbbiakban: BM EKO) vezetôje által jóváhagyott szakmai protokoll szerint kell végezni. Az egészségügyi és pszichológiai szakterület szakirányító szerve a szakmai és módszertani elöirások figyelembevételével biztositja az egységes szakmai elvek, módszerek és kritériumok érvényre juttatását."

A hatékonyságra a norma 5 . $\S$ (1) bekezdés a) és b) pontja ad választ: „a) egészségi, pszichikai, fizikai szempontból a meghatározott követelményrendszer szerint alkalmas-e a betöltendö szolgálati beosztás, munkakör ellátására; b) egészségének elöre látható károsodása nélkül alkalmas-e egyes, fokozott igénybevétellel, veszéllyel járó szolgálati feladatok, munkatevékenységek elvégzésére." 
Korszerüségre utalást a rendelet 6 . § (1) bekezdésében találhatunk: „,Az egészségi alkalmassági vizsgálatot az orvostudomány aktuális állásának megfelelöen az 1. mellékletben rögzitett kritériumok figyelembevételével kell végezni."

A leírtakból levonhatnánk a következtetést, hogy a jelenlegi kiválasztási rendszerben tükröződik a modernség, hiszen jóváhagyott szakmai protokollok alapján, a tudomány aktuális állásának megfelelően (feltételezi a megújulási készséget is) választják ki az alkalmas és feltételezhetően hatékony egyéneket.

Azt, hogy az egyes protokollok, standardok milyen mértékben tekinthetök szakmainak, nem tudom megítélni, mivel nincs se orvostudományi, se pszichológiai, sem pedig testnevelés-tudományi végzettségem, ezért ehhez a szakirodalmakban foglaltakat hívom segítségül, amelyek a következő eredményeket, kritikákat fogalmazták meg.

Krajcsovics és társai tanulmányuk konklúziójában azt emelték ki, hogy a rendőrség csak akkor lehet hatékony és eredményes, ha az állomány képes megfelelni az erőnléti, lélektani és szakmai kihívásoknak. Különféle szempontok (például gazdasági, személyügyi) alapján ez csak úgy képzelhető el, hogyha a kiválasztás "pályaorientált alkalmasságvizsgálattal" történik. ${ }^{11}$ Véleményük alapján a jó kiválasztásra fordított költségek úgy térülnek meg, hogy ezáltal megelőzhetők a hibás intézkedések, a felszerelés, a képzés és a korai nyugállományba helyezés anyagi vonzatai. Álláspontjuk szerint a magyar rendőrség kiválasztási rendszere korszerü, gondoskodik a szolgálatellátás követelményeinek megfelelő állományról.

Takács Péter egy kivizsgálási és utógondozási központ létrehozását szorgalmazta. Ezen kívül javaslatot tett a szituációs gyakorlatok alkalmazására, amellyel javítható lenne a személyek beválásának vizsgálata. ${ }^{12}$

Krajcsovics Pál és Félegyházi Csaba az alkalmatlansági okok vizsgálatából arra a következtetésre jutott, hogy az alkalmatlansághoz vezető leggyakoribb elváltozások gyakorlatilag megegyeznek a későbbi szolgálatképtelenség okaival. Eme összefüggés alapján úgy gondolták, hogy az egészségi alkalmasság követelményeit felül kell vizsgálni, és ebből következően nincsen lehetőség a kritériumok liberalizálására. Véleményük alapján a szervezet munkáját, a gazdaságos müködést döntően befolyásolja a megfelelő egészségi kondíciójú személyek alkalmazása.

11 Krajcsovics Pál - Félegyházi Csaba - Körmendiné Szabó Beatrix: i. m. 72. o.

12 Takács Péter: Gondolatok a rendőrség felvételi gyakorlatáról. Belügyi Szemle, 1995/2., 71-80. o. 
Balázs István és Takács Péter arra tért ki ${ }^{13}$, hogy időszerütlen dolog az alkalmassági vizsgálatokat főként orvos-egészségügyi jellegünek tekinteni, és nem elhanyagolható szempont a fizikai állóképesség vizsgálata sem. Véleményük szerint a rendőri pályára alkalmasság orvosi vonatkozása elengedhetetlen, és jóval komplexebb kérdés.

A szerzők arra hívták fel a figyelmet, hogy a helyes kiválasztás jelentős mértékben befolyásolja a fluktuációt. Az egészségügyi és pszichológiai vizsgálatok a szakma szempontjából kellö részletességgel történnek, sokan azonban már hallgatóként, vagy pályakezdő korukban alkalmatlanná válnak a hivatásra.

Véleményük szerint egy jól kiépített felvételi eljárás nemcsak az elvándorlást előzheti meg, hanem a „minőségi rendőr” segíthet a rendőrségre vonatkozó, negatív társadalmi sztereotípiák áthidalásában is. Másfelől a rossz kiválasztási rendszer azoktól is elveszi a lehetőséget, akik esetleg rátermettek a pályára.

A szerzők a kiválasztás javításának lehetőségét abban látták, hogy a szürést végzők és a fogadó (felvevő) szervek együttmüködve alakítanák a felvételi a követelményeket.

A cikk emellett a lélektani jellemvonások, a különbözö magatartásminták felismerésére, kiszürésére helyezi a hangsúlyt, és a kiválasztásának jövőbeli kiépítését is elsősorban ezen a téren képzelte el. Ezen kívül nagy jelentőséget tulajdonítottak a megfelelő önismeret tisztázásának is. A szerzők sokat várnak egy humán szolgáltatóközpont létrehozásától, amely lehetővé tenné az egységes alkalmassági vizsgálatokat, valamint beválásvizsgáló és utógondozó szervezetként is üzemeltethetö.

Bokodi Márta arra hívta fel a figyelmet, hogy a ,jelölt tulajdonságjegyeit az elvégzendö feladat, kötelesség, felelösség, munkakör pontos elemzésével kell összevetni. Így kerül megfelelö ember a megfelelö helyre!"'14

Csatai Tamás arról írt ${ }^{15}$, hogy a fejlődésnek nem a magasabb követelmények irányába kellett volna haladnia, hanem a szakterületi szükségletekhez kellene alkalmazkodni, és differenciálni a kritériumokat.

Csatai az 57/2009. (X. 30.) IRM-ÖM-PTNM együttes rendelet kapcsán kiemelte, hogy a norma nem a szükséges fejlődési irányt képviseli. A fizikai

\footnotetext{
13 Balázs István - Takács Péter: A rendőralkalmassági vizsgálat korszerüsíthetősége. Belügyi Szemle, 1997/12., 38. o.

14 Bokodi Márta: Hogyan érvényesülnek a személyiség dimenziói a kiválasztásban? Magyar Rendészet, 2004/2., 143. o.

15 Csatai Tamás: i. m.
} 
alkalmassági vizsgálatok teljesítési szintje emelkedett, ahelyett hogy azt dinamikus irányba alakították volna.

Az alkalmassági döntés rendszere kapcsán felhívta a figyelmet arra, hogy a mechanizmus továbbra sem változott, a szakterületek önálló döntéseket hoznak, nem együttesen bírálják el a jelentkezőt.

Véleménye szerint az egészségügyi protokoll továbbra is „tömegként” végzi a vizsgálatokat, nem történt meg a szükséges foglalkozás-egészségügyi szemlélet kialakítása.

Csatai az alkalmassági vizsgálatok jövőjét abban látja, hogy a személyek alkalmassági követelményeit a területi képviselökkel együtt közösen meghatározva, komplexen kell értékelni.

Megítélése szerint az alkalmasságvizsgálatok úgy újíthatók meg, ha azokat egy rendőrség által müködtetett központ végezné, amely egyidejüleg felelős lenne a beválásvizsgálatok elvégzéséért is.

Úgy véli, hogy az eddigieknél nagyobb szerepet kell tulajdonítani az önismeretnek és a beállítódásvizsgálatnak.

Németh János a fizikai alkalmassági vizsgálatok során alkalmazott gyakorlatok hatékonyságát elemezte. Végkövetkeztetése szerint az erőnlétet vizsgáló gyakorlatok a szükséges ,,célt kevésbé, vagy egyáltalán nem érik el "'16. A szerző a most alkalmazott vizsgálatok helyett javaslatot tett olyan gyakorlatok bevezetésére, amelyekkel több képesség is vizsgálható. ${ }^{17}$

Felsorolásszerüen összegzem a szakirodalmi ajánlások megállapításait:

- A fizikai-egészségi-pszichológiai vizsgálatok alkalmazását valamennyi érintett szükségesnek tartja, hiszen olyan javaslat nem született, amely valamelyik mellőzésére irányulna.

- Egyes szerzők a vizsgálatok szigorítása mellett, mások pedig a szintemelkedés ellen vagy a vizsgálati módszerek átalakítása mellett érvelnek.

- Több szerző vélekedik úgy, hogy a hatékonyságot, valamint a fluktuációt döntően befolyásolja a helytelen kiválasztás.

- A szakterületek önállóan döntenek ahelyett, hogy komplex értékelés történne.

- A területi szervek nem vesznek részt az alkalmasság meghatározásában.

- A kiválasztási eljárás tömegeket kezel.

- A kiválasztást a rendőrségen belül egy központosított szervezeti egységen belül képzelik el.

\footnotetext{
16 Németh János: A rendőri munka során szükséges kondicionális képesség, és az előírt feladatok elemzése, értékelése. Magyar Rendészet, 2013/1., 138. o.

17 A javasolt vizsgálatok részletezése a téma szempontjából nem releváns.
} 
A következőkben az előbbi megállapításokra szeretnék reagálni a statisztikai adatok és a külföldi rendőrségek által alkalmazott módszerek segítségével.

A Nemzeti Közszolgálati Egyetem Rendészettudományi Karára ${ }^{18}$ jelentkezők alkalmassági vizsgálatainak statisztikai adataival kezdem (táblázat).

Kimutatás a Nemzeti Közszolgálati Egyetem Rendészettudományi Kar alkalmassági vizsgálatának eredményeiről

\begin{tabular}{|l|c|c|c|c|}
\hline Alkalmassági vizsgálatok & 2013 & 2014 & 2015 & 2016 \\
\hline Fizikai vizsgálat & 783 & 878 & 840 & 668 \\
Alkalmas & 486 & 558 & 443 & 299 \\
Alkalmatlan & 257 & 347 & 287 & 485 \\
Nem jelent meg & & & & \\
& & & & \\
Egészségi-pszichológiai vizsgálat & $451 / 116$ & $517 / 144$ & $427 / 135$ & $407 / 86$ \\
Alkalmas (I. fok/II. fok) & $310 / 98$ & $335 / 79$ & $386 / 174$ & $244 / 76$ \\
Alkalmatlan (I. fok/II. fok) & $22 / 33$ & $26 / 54$ & $27 / 33$ & $17 / 58$ \\
Nem jelent meg (I. fok/II. fok) & & & & \\
& & & & \\
Pályaorientációs beszélgetés & 529 & 599 & 519 & 454 \\
Alkalmas & 4 & 4 & 4 & 5 \\
Alkalmatlan & 34 & 59 & 40 & 34 \\
Nem jelent meg & & & & \\
\hline
\end{tabular}

A táblázatból látható, hogy vizsgálatok valóban tömegeket kezelnek, ez jelentősen megnehezíti az alkalmasság mélyebb vizsgálatát. Jóval nehezebb helyzet, amikor a rendőrség létszámának jelentős növelését kell végrehajtani.

A tömegek kezelésére például az angol és walesi rendőrök kiválasztásakor online előszürő rendszert alkalmaznak ${ }^{19}$. Ez költséges megoldás ugyan, viszont lehetővé teszi a szakmai szempontok szerint előszürt jelöltekre koncentrálást az alkalmassági vizsgálatok során.

Saját meglátásom szerint a fizikai alkalmassági vizsgálat túlzottan domináns. A statisztikából egyértelműen kiderül, hogy a jelentkezők nagyjából fele elbukik az első akadályon.

Természetesen azt sem szabad elfelejteni, hogy az alkalmassági vizsgálatok közül az erőnléti a legolcsóbban kivitelezhető, ebből a szempontból pedig logikus az első helye. Azonban pont a fizikai állapot a legkönnyebben

18 Azért csak a rendészettudományi kar adatait tüntetem fel, mert kizárólag szemléltetésként használom, mélyebb elemzésre nem kerül sor.

19 Lásd Mogyoródi Gergely: Anglia és Wales hivatásos rendőri állományának kiválasztási eljárása és annak összevetése a hazai követelményekkel. Magyar Rendészet, 2016/6. 
alakítható, és ha a jelentkező testileg és lelkileg alkalmas (itt jön képbe a Csatai által említett együttes értékelés hiánya), akkor nem lenne szabad, hogy akadálya legyen az egyetem megkezdésének. Meglátásom szerint inkább a képzés feladata a fizikai felkészítés, nem pedig az egyéné.

A javasolt dinamikus erőnléti vizsgálatokra jó példa az ír rendőrség által alkalmazott fizikaikompetencia-vizsgálatok rendszere. ${ }^{20}$

Az alkalmassági vizsgálatok követelményeinek változása kapcsán utalni kell az angol és walesi rendőrség módszerére: a kritériumokat mind az egészségi, mind a fizikai vizsgálat terén csökkentették.

A jelenlegi rendszer kiemelkedő hatékonysága ellen szól például, hogy a rendészettudományi karon 2016-ban a rendvédelmi szakirányok vonatkozásában a lemorzsolódás 14 százalék volt (220 felvett hallgatóból 31 leszerelt), míg 2015-ben 9,6 százalék (258 felvett hallgatóból 25 szerelt le) ${ }^{21}$, ami jelentősen megnehezíti a humánerőforrás-tervezést.

Nem értek egyet azokkal a megállapításokkal, amelyek szerint mind a rendőrség hatékonyságát, mind pedig a fluktuációt döntően befolyásolná az alkalmassági vizsgálatok rendszere.

Véleményem szerint a kiválasztás hatékonysága pontosan a tanulmányok megkezdéséig és az ottani körülményekhez való alkalmazkodásig terjed, mivel ettől kezdve olyan mennyiségü környezeti tényező befolyásolja a hallgató sikerességét/sikertelenségét, hogy nem lehet a kiválasztási módszerek és a szolgálat hatékonysága között egyértelmü kölcsönhatást megállapítani.

Azzal a meglátással egyetértek, hogy felvevő szervek szerepe jóval fontosabb kellene hogy legyen, hiszen ők azok, akik képesek meghatározni az aktuális igényeket. Emellett persze kérdés az is, hogy azok a képességek, készségek, amelyek a felvétel idején időszerünek számítottak, a kettő-négy éves képzés végére is annak tekinthetők-e.

A központosított, rendőrségen belül müködő kiválasztással foglalkozó egység kapcsán megjegyezném, hogy ez sem a polgári életben, sem pedig a nyugati rendőrségek (például az északír) ${ }^{22}$ esetében nem újdonság. Az északír rendőrség a kiválasztás egyes folyamatainak lebonyolításával külső gazdasági társaságot bízott meg, és csak az általuk megfelelőnek találtakkal végeztetik el az alkalmassági vizsgálatokat.

20 Mogyoródi Gergely: Az An Garda Síochána (az ír rendőrség) képzési és állománykiválasztási rendszere. Magyar Rendészet, 2016/5., 123-137. o.

21 Megjegyzés: az adatok valamennyi rendészeti szakirányos hallgatóra, nem csak a rendőrökre vonatkoznak. Lásd Verhóczki János: Feljegyzés a tisztjelölt hallgatók lemorzsolódásáról a felvétel és az alapkiképzés során. Nemzeti Közszolgálati Egyetem, Budapest, 2016

22 Lásd www.joinpsni.co.uk/downloads/Guidance-for-Applicants.pdf 
Álláspontom szerint tehát nem lehet egyértelmüen meghatározni, hogy a jelenlegi felvételi eljárásra tekinthetünk-e a modern rendőrség egyik jellemzőjeként. A felsorakoztatott szempontok lehetőséget adnak a téma aktualitásának felismerésére, de a kérdés eldöntéséhez további kutatások szükségesek.

\section{IRODALOM}

Balázs István - Takács Péter: A rendőralkalmassági vizsgálat korszerüsíthetősége. Belügyi Szemle, 1997/12.

Bárczi Géza - Országh László (szerk.): A magyar nyelv értelmező szótára. Akadémiai Kiadó, Budapest, 1959-1962

Bokodi Márta: Hogyan érvényesülnek a személyiség dimenziói a kiválasztásban? Magyar Rendészet, 2004/2.

Csatai Tamás: A rendőrré válás és szolgálatellátás alatti pályaalkalmassági követelmények alakulása az 1800-as évek végétől napjainkig. Belügyi Szemle, 2010/7-8.

Finszter Géza: A rendészet elmélete és a rendészeti eszközrendszer. Nemzeti Közszolgálati és Tankönyvkiadó Zrt., Budapest, 2013

Krajcsovics Pál - Félegyházi Csaba - Körmendiné Szabó Beatrix: Az alkalmassági vizsgálat helye a Belügyminisztérium egészségügyi szolgálatában. Rendészeti Szemle, 1994/1.

Krajcsovics Pál - Félegyházi Csaba: Az egészségi alkalmassági vizsgálat társadalomorvostani és gazdasági vonatkozásai. Belügyi Szemle, 1997/12.

Mogyoródi Gergely: Az An Garda Síochána (az ír rendörség) képzési és állománykiválasztási rendszere. Magyar Rendészet, 2016/5.

Mogyoródi Gergely: Anglia és Wales hivatásos rendőri állományának kiválasztási eljárása és annak összevetése a hazai követelményekkel. Magyar Rendészet, 2016/6.

Németh János: A rendőri munka során szükséges kondicionális képesség, és az elöirt feladatok elemzése, értékelése. Magyar Rendészet, 2013/1.

Takács Péter: Gondolatok a rendőrség felvételi gyakorlatából. Belügyi Szemle, 1995/2.

Verhóczki János: Feljegyzés a tisztjelölt hallgatók lemorzsolódásáról a felvétel és az alapkiképzés során. Nemzeti Közszolgálati Egyetem, Budapest, 2016 